\title{
PYY wt Allele
}

National Cancer Institute

\section{Source}

National Cancer Institute. PYY wt Allele. NCI Thesaurus. Code C104811.

Human PYY wild-type allele is located in the vicinity of $17 q 21.1$ and is approximately $52 \mathrm{~kb}$ in length. This allele, which encodes peptide YY protein, plays a role in signaling that modulates digestion. Genetic variations in this gene may contribute to obesity. 